\title{
Removal of nutrients and organic pollutants from domestic wastewater treatment by sponge-based moving bed biofilm reactor
}

\author{
Huynh Tan Nhut, Nguyen Tri Quang Hung ${ }^{\dagger}$, Tran Cong Sac, Nguyen Huynh Khanh Bang, \\ Tran Quang Tri, Nguyen Trung Hiep, Nguyen Minh Ky \\ Faculty of Environment and Natural Resources, Nong Lam University of Ho Chi Minh City, Ho Chi Minh City 700000, Vietnam
}

\begin{abstract}
This study evaluates the efficiency of domestic wastewater treatment via Sponge-Based Moving Bed Biofilm Reactor (S-MBBR). The laboratory-based treatment plan uses polyurethane sponge with a specific surface area was $260 \mathrm{~m}^{2} / \mathrm{m}^{3}$ as a carrier. The treatment plan operated under four different organic load rate: OLR1 $=0.4 \mathrm{~kg} \mathrm{BOD} / \mathrm{m}^{3}$.day; OLR2 $=0.6 \mathrm{~kg} \mathrm{BOD} / \mathrm{m}^{3}$. day; OLR3 $=0.8 \mathrm{~kg} \mathrm{BOD} / \mathrm{m}^{3}$. day; and OLR4 $=1.0 \mathrm{~kg}$ BOD $/ \mathrm{m}^{3}$. day. During $80 \mathrm{~d}$ of the experiment, the highest treatment efficiency was at the organic load rate of $0.4 \mathrm{~kg} \mathrm{BOD} / \mathrm{m}^{3}$.day, with COD, SS, TN and $\mathrm{TP}$ were found to be $85.0 \pm 12.9 \%, 85.7 \pm 5.3 \%, 68.9 \pm 1.7 \%$, and $40.3 \pm 0.2 \%$, respectively. In which, the influent SS concentration were from 117.3 to $126.0 \mathrm{mg} / \mathrm{L}$, the effluent concentration were in ranged 18.0 to $34.22 \mathrm{mg} / \mathrm{L}$, respectively. The values of influent and effluent COD were $298.8 \pm 12.88$ and $44.8 \pm 3.78 \mathrm{mg} / \mathrm{L}$ in turn. The OLR1 influent TN, TP concentrations were respectively $47.9 \pm 2.11$ and $3.6 \pm 0.15 \mathrm{mg} / \mathrm{L}$; the effluent TN, TP concentration were $14.9 \pm 0.18$ and $2.2 \pm 0.06 \mathrm{mg} / \mathrm{L}$, respectively. The study suggests that the effluent is within the allowable limits of National technical regulation on domestic wastewater (Column B1), indicating the applicability of S-MBBR for the domestic wastewater treatment plant.
\end{abstract}

Keywords: Activated sludge, Domestic wastewater, S-MBBR, Sponge

\section{Introduction}

Rapid urbanization has imposed high pressure on freshwater resources with increasing water demand (due to increasing population) and decreasing water quality (due to waste water pollution). To protect water resources, it is compulsory to have appropriate wastewater treatment technology for each specific contamination factor. Among factors affecting water quality, organic pollution is one of the leading causes of several phenomena such as eutrophication, reduction of dissolved oxygen, accumulation of toxins, etc. [1]. Removing organic pollution from wastewater, therefore, is necessary to improve the effluent quality to minimize harmful effects on the freshwater resources.

Biological treatment processes, particularly activated sludge is considered the primary solution for effective wastewater treatment containing high organic content. Activated sludge process, however, has some disadvantages such as a large amount of sludge generated, long hydraulic retention time (HRT) that leading to a large volume of construction, the potential occurrence of difficult sedimentation phenomenon and low efficiency of nitrogen removal [2]. Biofilm processes have shown high efficiency in removing organic pollution and overcoming the drawbacks of conventional activated sludge processes [3-4]. Therefore, biofilm technology is increasingly applied in wastewater treatment, with several technologies developed recently including Trickling Filter, Submerged Biofilter, Moving Bed Biofilm Reactor (MBBR), Fluidized Bed Biological Reactor, etc. [5-8]. Among them, MBBR technology, in which microorganisms grow up a biofilm on suspended biofilm carriers, has been proved to be a simple and effective treatment technology, particularly for wastewater with high organic content, microorganisms can grow up a biofilm on suspended biofilm carriers [7, 9].

MBBR technology was significantly developed in the period from 1980s to 1990s in Norway [10]. The technology bases on the traditional activated sludge process with suspended biofilm carrier used as a binding site for microorganisms. As suspended biofilm carrier is the key element of MBBR technology, carrier
Received July 07, 2019 Accepted September 03, 2019

${ }^{\dagger}$ Corresponding author

Email: quanghungmt@hcmuaf.edu.vn Tel: +84-3-87220723 medium, provided the original work is properly cited.

Copyright (C) 2020 Korean Society of Environmental Engineers 
selection focus on the material, surface roughness, and surface area to optimize the growth rate of biological membranes [11-12]. At present, there are many types of materials studied to be applied in MBBR technology, such as plastic, foam, activated carbon, fiber, and ceramic, etc. [13-14]. Among these options, sponge-based MBBR (S-MBBR) is considered the new opportunity for attached growth biological process, owing to their high mechanical strength, large specific surface area and very high surface roughness for microorganisms to grow [15]. Moreover, many studies have demonstrated that using foam in S-MBBR tanks is highly effective in wastewater treatment. Chu and Wang [16] used 20\% carrier polyurethane (surface area $900 \mathrm{~m}^{2} / \mathrm{m}^{3}$ ) in MBBR tanks to treat artificial wastewater with low $\mathrm{C} / \mathrm{N}$ ratio. In which, the removal efficiency of organic matter was $90 \%$ and $65 \%$ of ammonium at the HRT of $14 \mathrm{~h}$. Using polyurethane foam substrates (surface area of $1120 \mathrm{~m}^{2} / \mathrm{m}^{3}$ ) with $40 \%$ volume of MBBR tanks at $5 \mathrm{~h}$ HRT had removal efficiency of COD and ammonium of $80 \%$ and $96.3 \%$ respectively [17]. Zhang et al. [18] also showed S-MBBR can remove organic and ammonium over $90 \%$ at $12 \mathrm{~h} \mathrm{HRT} \mathrm{from} \mathrm{domestic} \mathrm{wastewater.} \mathrm{The} \mathrm{sponge-mem-}$ brane bioreactor provides better performance than activated sludge such as smaller required area and higher quality of treated wastewater [19]. In addition, the effluent quality parameters can be met for agricultural or irrigation purposes. Sponge has been considered as a suitable medium in improved organic and nutrients removal [20-21]. In the recent years have been successfully used and studied the sponge membrane bioreactor for the treatment of many effluents including catfish farm and hospital wastewater [19, 22-23].
Although sponge based MBBR technology has been studied extensively in many countries, understanding of this technology is still limited in developing countries (e.g. Vietnam). In contrast, the pollution caused by organic substances and the concentration of nutrients in wastewater have been at an alarmed level. Therefore, this study aims to evaluate the efficiency in treating domestic wastewater via S-MBBR technology through the removal of nutrients and organic pollutants in developing countries.

\section{Materials and Methods}

\subsection{Wastewater Characteristics}

Wastewater used in this study was taken from the collection tank of Co May Dormitory (Nong Lam University, Ho Chi Minh City). The characteristics of the research wastewater are shown in Table 1.

\subsection{Experimental Set-up}

The media in this case were used sponge polyurethane with the membrane surface area of $260 \mathrm{~m}^{2} / \mathrm{m}^{3}$, with the density of $0.8 \mathrm{~kg} / \mathrm{m}^{3}$ and produced by a commercial company in Singapore (Qian Hu Co Ltd, Singapore). An optimized sponge cube of $8 \mathrm{~cm}^{3}(2 \mathrm{~cm}$ $\times 2 \mathrm{~cm} \times 2 \mathrm{~cm}$ ) was selected to introduce into the reactor with the occupation of $20 \%$ reactor volume. Model S-MBBR (Fig. 1) includes Sewage tank, S-MBBR tank, sedimentation tank, final effluent tank, sludge tank. The model design parameters are shown in Table 2.

Table 1. Characteristics of the Dormitory Wastewater used in the Experiment

\begin{tabular}{|c|c|c|c|c|}
\hline Parameter & Unit & Range $(n=5)$ & $\begin{array}{c}\text { QCVN 14:2008/BTNMT } \\
\text { (Colum B) }\end{array}$ & $\begin{array}{c}\text { European Communities } \\
(91 / 271 / \mathrm{EEC})\end{array}$ \\
\hline $\mathrm{pH}$ & - & $6.9 \pm 0.3$ & $5.0-9.0$ & - \\
\hline DO & $\mathrm{mg} / \mathrm{L}$ & $0.4 \pm 0.1$ & $\geq 2^{\mathrm{a}}$ & - \\
\hline $\mathrm{BOD}_{5}\left(20^{\circ} \mathrm{C}\right)$ & $\mathrm{mg} / \mathrm{L}$ & $150 \pm 20$ & 50 & 25 \\
\hline COD & $\mathrm{mg} / \mathrm{L}$ & $300 \pm 10$ & $150 \mathrm{~b}$ & 125 \\
\hline TSS & $\mathrm{mg} / \mathrm{L}$ & $120 \pm 10$ & 100 & 35 \\
\hline Ammonia $\left(\mathrm{NH}_{4}^{+}\right)$ & $\mathrm{mg} / \mathrm{L}$ & $40.8 \pm 20$ & 10 & - \\
\hline Nitrate $\left(\mathrm{NO}_{3}^{-}\right)$ & $\mathrm{mg} / \mathrm{L}$ & $1.5 \pm 0.7$ & 50 & - \\
\hline Total Phosphorus (TP) & $\mathrm{mg} / \mathrm{L}$ & $3.8 \pm 2$ & $6 b$ & 1 \\
\hline
\end{tabular}

QCVN 14:2008/BTNMT - National technical regulation on domestic wastewater

${ }^{a}$ QCVN 39:2011/BTNMT - National technical regulation on quality of water for irrigation

${ }^{b}$ QCVN 40:2011/BTNMT - National technical regulation for industrial wastewater (B)

Table 2. The Detail Information of Design Parameters

\begin{tabular}{lccc}
\hline Parameters & Materials & Dimension (cm) & Volume optimistic (Liter) \\
\hline Sewage tank & Plastic & $25 \times 50\left(^{*}\right)$ & 100 \\
\hline S-MBBR tank & Glass & $26 \times 15 \times 68\left(^{* *}\right)$ & 27 \\
\hline Sedimentation tank & Glass & $15 \times 15 \times 68\left(^{* *}\right)$ & 15 \\
\hline Final effluent tank & Plastic & $25 \times 30\left(^{*}\right)$ & 60 \\
\hline Sludge tank & Plastic & $15 \times 15\left(^{*}\right)$ & 10 \\
\hline
\end{tabular}

Note: $\left(^{*}\right)$ W $\times$ H (W: Width, H: Hight); $\left({ }^{* *}\right)$ L $\times$ W $\times$ H (L: Length, W: Width, H: Hight) 


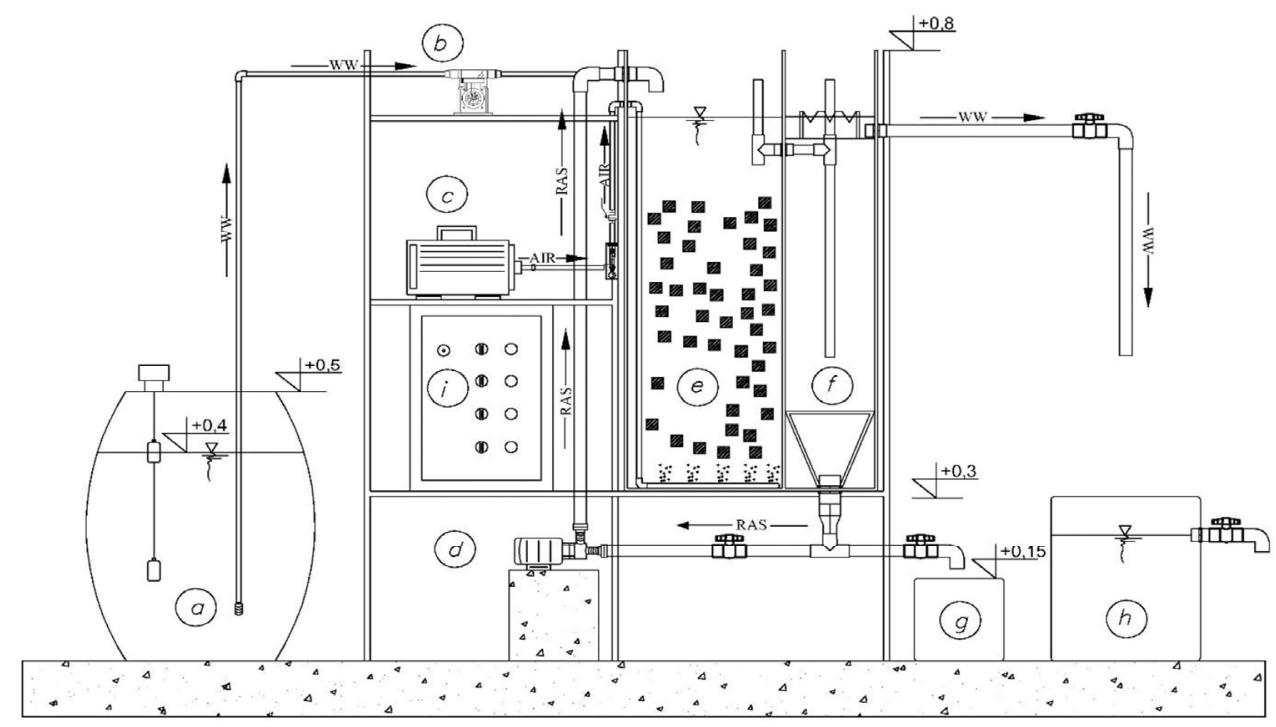

Fig. 1. Schematic detail of the S-MBBR system. ((a) Seawage tank; (b) Quantitative pumb; (c) Air pumb; (d) Sludge pumb; (e) S-MBBR tank; (f) Sedimantation tank; (g) Slugde tank; (h) Final effluent tank; (i) Electric cabinet, RAS. Return activated sludge, WW. Wastewater).

\subsection{Operational Conditions of S-MBBR System}

The wastewater is steadily led into the S-MBBR tank from the sewage tank by a pump with the flow corresponding to the calculated load. The research model is operated with four different organic loading rates corresponding to four phases during $80 \mathrm{~d}$ of the experiment. At present, urban domestic wastewater in Vietnam was a mixture of grey wastewater and black wastewater. Before mixing with the grey wastewater and discharged to the treatment plan process, the black wastewater was pretreated by a septic tank. The character of wastewater in Co May Dormitory also includes grey wastewater, black wastewater as typical urban domestic wastewater in Vietnam (Ho Chi Minh City). For this study, the research model was operated with four organic loading rates (Table 3) around the popular concentration pollutant to evaluate the treatment efficiency of S-MBBR. In the start-up phase, the average DO concentration was kept at $5.3 \pm 0.5 \mathrm{mg} / \mathrm{L}$. The average DO concentration and $\mathrm{pH}$ for each OLRs ranged from 1.5 to 3.0 $\mathrm{mg} / \mathrm{L}$ and $6.9 \pm 0.2$, respectively during the operating period. The calculated BOD:N:P ratio of the wastewater was 100:5:1. In this study, the calculated BOD:N:P ratio was 100:5:1 of the wastewater which was prepared with glucose $\left(\mathrm{C}_{6} \mathrm{H}_{12} \mathrm{O}_{6}\right)$, ammonium sulfate $\left(\left(\mathrm{NH}_{4}\right)_{2} \mathrm{SO}_{4}\right)$, potassium dihydrogen orthophosphate
$\left(\mathrm{KH}_{2} \mathrm{PO}_{4}\right)$. The detail information of operation conditions is shown in Table 3.

In the study of Kermani et al. [24], the authors maintained moving bed biofilm experiment at the HRT equal to 4 and $12 \mathrm{~h}$ for municipal wastewater, respectively. HRT of 6 and $12 \mathrm{~h}$ showed better effluent quality and enhanced nutrient removal in the S-MBBR [13], while, Zhang et al. [18] conducted HRT of 12 and $24 \mathrm{~h}$, respectively. In this study, in order to evaluate the ability to nutrient and organic compounds removal at different OLRs, S-MBBR tested wastewater flows: 3.0, 4.5, 6.0, 7.5 liters/hour corresponde to HRT of 9.0, 6.0, 4.5 and $3.6 \mathrm{~h}$ accordingly. Organic loading rate (OLR) is from 0.4 to $1.0 \mathrm{kgBOD} / \mathrm{m}^{3}$.day. A start-up period of about 2 weeks for biofilm growth on the sponge carrier was followed by $15 \mathrm{~d}$ of the testing period at the organic loading rate $0.2 \mathrm{kgBOD} / \mathrm{m}^{3}$.day ( $50 \%$ of OLR1). The steady state condition was defined as the period during which the effluent quality was relatively constant at a constant loading and that will be carried out comparative with National technical regulation on domestic wastewater limits (QCVN 14-MT:2015/BTNMT, column B1) with regard to the parameters of COD, TN, TP and SS. After achieving the conditions, operate with subsequent organic loading rate to evaluate the treatment efficiency.

Table 3. Information of Operational Conditions

\begin{tabular}{|c|c|c|c|c|c|}
\hline Conditions & Unit & OLR 1 & OLR 2 & OLR 3 & OLR 4 \\
\hline Organic loading rate (OLR) & $\mathrm{kgBOD} / \mathrm{m}^{3} \cdot \mathrm{d}$ & 0.4 & 0.6 & 0.8 & 1.0 \\
\hline Influent pump & $\mathrm{L} / \mathrm{h}$ & 3.0 & 4.5 & 6.0 & 7.5 \\
\hline Internal sludge pump & $\mathrm{mL} / \mathrm{min}$ & 200 & 200 & 200 & 200 \\
\hline Air flow rate & $\mathrm{L} / \mathrm{min}$ & $10-15$ & $10-15$ & $10-15$ & $10-15$ \\
\hline HRT & $\mathrm{h}$ & 9.0 & 6.0 & 4.5 & 3.6 \\
\hline Sludge retention time (SRT) & $\mathrm{d}$ & 15 & 15 & 15 & 15 \\
\hline MLSS & $\mathrm{mg} / \mathrm{L}$ & 2,800 & 2,800 & 2,800 & 2,800 \\
\hline
\end{tabular}




\subsection{Statistical and Analytical Methods}

The performance of the lab-scale S-MBBR, samples were taken from the sewage tank, the S-MBBR tank and the final effluent tank. COD, SS, $\mathrm{NH}_{4}{ }^{+}-\mathrm{N}, \mathrm{NO}_{2}^{-}-\mathrm{N}, \mathrm{NO}_{3}^{-}-\mathrm{N}$, TKN, TP, $\mathrm{pH}$ were measured on samples every day. Parameters such as COD, SS, $\mathrm{NH}_{4}{ }^{+} \mathrm{N}$, $\mathrm{NO}_{2}^{-}-\mathrm{N}, \mathrm{NO}_{3}^{-}-\mathrm{N}, \mathrm{TKN}, \mathrm{TP}$ were analyzed according to "Standard Methods for the Examination of Water and Wastewater" (APHA, 2012). $\mathrm{BOD}_{5}$ was measured by improved Winkler at $20^{\circ} \mathrm{C}$ in 5 d. Other parameters such as $\mathrm{DO}$ and $\mathrm{pH}$ were directly test by Water Quality Checker WQC-22A (DKK-TOA, Japan).

To determine the sludge concentration include the total of sludge in sponges and in bulk liquid of the reactor, which the attached biomass in the sponge was converted into mixed liquor suspended solids (MLSS) concentration. Dry dish at least $1 \mathrm{~h}$ in an oven at $105^{\circ} \mathrm{C}$, cool dish in desiccator to balance temperature, and weight. After that, ten sponge carriers from MBBR reactor, then that washed by distilled. Combine distilled water and activated sludge placed in a cup with the real weight, and that were dried at $105^{\circ} \mathrm{C}$ for $2 \mathrm{~h}$, followed by weighing again. The biomass on the carriers was determined based on the weight difference before and after adding activated sludge. In addition, ANOVA analysis was applied to find significantly statistical differences between experiments at $\mathrm{p}<$ 0.05. All statistical analyses were performed using Origin Version 6.0 with significance was $\mathrm{p}<0.05$.

\section{Results and Discussions}

\subsection{Performance of the Start-up Phase}

As can be seen from Table 4, the efficiencies of the start-up phase for more than $85.7 \pm 2.63 \%$ COD and $76.2 \pm 3.45 \%$ SS on average were achieved in S-MBBR. Nutrient removal of S-MBBR found significant changes in the testing time, as $\mathrm{NH}_{4}{ }^{+}-\mathrm{N}$ and TP removal were $85.5 \pm 3.26 \%$ and $19.6 \pm 3.61 \%$, respectively.

Table 4. Effective Treatment of Pollutants During the Testing Period.

\begin{tabular}{lccc}
\hline Parameter & Influent $(\mathbf{m g} / \mathbf{L})$ & Effluent $(\mathrm{mg} / \mathrm{L})$ & Efficiency (\%) \\
\hline $\mathrm{COD}$ & $184 \pm 32.09$ & $25.4 \pm 1.67$ & $85.7 \pm 2.63$ \\
\hline $\mathrm{NH}_{4}{ }^{+}-\mathrm{N}$ & $38.02 \pm 5.76$ & $5.36 \pm 0.59$ & $85.5 \pm 3.26$ \\
\hline $\mathrm{SS}$ & $116 \pm 8.94$ & $28 \pm 3.61$ & $76.2 \pm 3.45$ \\
\hline $\mathrm{TP}$ & $3.56 \pm 0.10$ & $2.86 \pm 0.10$ & $19.6 \pm 3.61$ \\
\hline
\end{tabular}

Additionally, attached-biomass growth also achieved a steady state. In S-MBBR, the MLSS concentration of mixed liquor was steady at $2,644 \pm 170.4 \mathrm{mg} / \mathrm{L}$. For the sponge, the biofilm was mainly developed on the outer surface of the carrier. However, sponge possesses a large number of pores with the large surface area that microorganisms can be attached into the pores, and then developed over surfaces area [5].

\subsection{Efficiency of Pollutants Treatment from Domestic Wastewater}

\subsubsection{Suspended solids (SS) removal}

Fig. S1 show the average influent/effluent SS concentration and removal efficiency under different organic loading rate. Influent SS concentration is relatively stable, ranging from 117.3 to 136.0 $\mathrm{mg} / \mathrm{L}$. During the experiment, SS removal efficiency fluctuates from 71.0 to $86.0 \%$ (78.5 $\pm 2.25 \%)$, with effluent SS concentration reaches 18.0-34.22 mg/L (26.0 $\pm 11.52 \mathrm{mg} / \mathrm{L})$. A notable pattern is the decrease of SS removal efficiency when increasing organic loading rate. A potential reason is sheared microorganisms from the carriers, contributing to an increase in effluent SS concentration [25].

Study results in Fig. S1 shows the suspended solids treating efficiency of S-MBBR technology is more than $70 \%$. In the case of suspended solids removal efficiency, SS eliminating efficiency is highest in the $5^{\text {th }}$ day at OLR1 $(91.8 \%)$. It could be recognized that the SS did not correspond to among the highest and lowest values of the influent, effluent or performance. This could be explained by the change and differences of HRTs from 9.0 to $3.6 \mathrm{~h}$ among OLRs. Fig. S1 showed the highest and lowest influent SS concentration were maintained with $136 \mathrm{mg} / \mathrm{L}$ (19th day) at OLR1 and $100 \mathrm{mg} / \mathrm{L}$ ( $66^{\text {th }}$ day) at OLR4, respectively. While, the SS removal efficiency demonstrated high value of $91.8 \%$ at OLR1 and this correspond to effluent SS of $10 \mathrm{mg} / \mathrm{L}$. With the increase in OLR phases, the reactor decline of SS removal to $68.3 \%$ in 64 th day at OLR4. The observation of OLRs showed in the phase 4 could be due to the sudden change by the loading rate. In addition, removal efficiency of pollutants (suspended solids) in OLR1 is usually higher than OLR2, OLR3 and OLR4 $(\mathrm{p}<0.05)$.

\subsubsection{Organic matter removal}

Similar to SS removal efficiency, COD removal efficiency reduced gradually when the organic loading rate increased from 0.6 $\mathrm{kgBOD} / \mathrm{m}^{3}$.day to $1.0 \mathrm{kgBOD} / \mathrm{m}^{3}$.day. As shown in Fig. 2, influent COD concentration has an average value of $290 \pm 11.83 \mathrm{mg} / \mathrm{L}$. Treatment efficiency also decreased from 0.4 to $1.0 \mathrm{~kg}$ $\mathrm{BOD} / \mathrm{m}^{3}$.day when the organic loading rate increase. When the system was operated at $0.4 \mathrm{kgBOD} / \mathrm{m}^{3}$.day organic loading rate (OLR1), the COD removal efficiency was $85 \pm 2 \%$, corresponding to average effluent concentration of $44.8 \pm 3.78 \mathrm{mg} / \mathrm{L}$. At organic loading rate of $0.6 \mathrm{~kg} \mathrm{BOD} / \mathrm{m}^{3}$.day (OLR2), the COD removal efficiency was also stable at $85 \pm 2 \%$, corresponding to effluent concentration of $43.03 \pm 5.29 \mathrm{mg} / \mathrm{L}$. This result is similar to that of which found removal efficiency of COD reaching 80.0-86.0\% corresponding to COD concentration of 45.0-60.0 $\mathrm{mg} / \mathrm{L}$ for artificial wastewater with similar quality of domestic wastewater [11]. However, this result is lower than that of Deng et al. [13], in which artificial sewage was used to evaluate treatment efficiency of polyester-polyurethane foam material combining with an outside plastic ring. Specifically, an S-MBBR with $20 \%$ tank volume filled with microbial sticking has COD treatment efficiency reaches over 90\% [13].

COD treating efficiency reduces when the organic load rises from 0.4 (corresponding to $85.0 \%$ efficiency) to $1.0 \mathrm{kgBOD} / \mathrm{m}^{3}$.day (corresponding to $70.1 \%$ efficiency). Detailed values of COD before and after treatment in $80 \mathrm{~d}$ are shown in Fig. 2. Initial COD concentration is high but become low after treatment $(<50 \mathrm{mg} / \mathrm{L}$ in OLR1 to OLR2 and $<100 \mathrm{mg} / \mathrm{L}$ in OLR3 to OLR4). Meanwhile, according to QCVN 40:2011/BTNMT - National technical regulation 


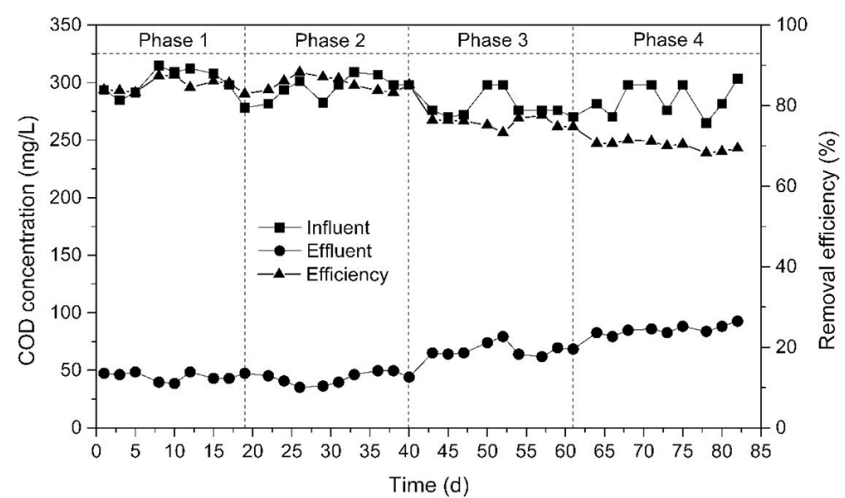

Fig. 2. COD removal efficiency during the experimental.

for industrial wastewater (Column A, B), upper limit of COD are 75 and $150 \mathrm{mg} / \mathrm{L}$ accordingly. In addition, the COD concentration also met European Communities' effluent guidelines standards. This shows the potential of S-MBBR technology in the treatment of domestic wastewater.

At $0.8 \mathrm{kgBOD} / \mathrm{m}^{3}$.day organic loading rate (OLR3), COD removal efficiency reduced to $76.0 \pm 1 \%$, corresponding to average effluent concentration of $67.92 \pm 5.66 \mathrm{mg} / \mathrm{L}$. At an organic loading rate of $1.0 \mathrm{kgBOD} / \mathrm{m}^{3}$.day (OLR4), treatment efficiency decreased further to $70.1 \pm 1 \%$ (corresponding to effluent concentration of 85.46 $\pm 13.99 \mathrm{mg} / \mathrm{L}$ ). When the HRT decreased from $6 \mathrm{~h}$ to $3.6 \mathrm{~h}$, it is not enough time for microorganisms to oxidize organic compounds to synthesize cells. Besides, removing SS also contributes to reducing effluent COD concentration but the concentration of SS increases to $28.0 \pm 3.6 \mathrm{mg} / \mathrm{L}$ (OLR3) and $34.2 \pm 2.7 \mathrm{mg} / \mathrm{L}$ (OLR4) in this period. On the other hand, the biomass in the S-MBBR tank also decreased from 3,056 $\pm 339 \mathrm{mg} / \mathrm{L}$ to $2,664 \pm 315 \mathrm{mg} / \mathrm{L}$. These may be the reasons for the processing efficiency to no longer reach over $80 \%$ as in the period of OLR1 and OLR2. Thus, for COD removal efficiency to reach over $80 \%$, an organic loading rate is chosen suitable in the range of $0.4-0.6 \mathrm{kgBOD} / \mathrm{m}^{3}$.day and the HRT must ensure over $6 \mathrm{~h}$. Furthermore, removal efficiency of OLRs of 1 and 2 is the highest with higher than $85 \%$, and the OLR1 was not different the OLR2 ( $p>0.05)$. However, OLRs of 1 and 2 was higher and statistically significant difference with OLRs of 3 and $4(\mathrm{p}<0.05)$.

\subsection{Efficiency of Nutrient Removal from Domestic Wastewater}

\subsubsection{Nitrogen removal}

Fig. 3 and Fig. S2 show the transformation of nitrogen compounds in the average concentration of $\mathrm{NH}_{4}{ }^{+}-\mathrm{N}, \mathrm{NO}_{3}{ }^{-}-\mathrm{N}, \mathrm{NO}_{2}{ }^{-} \mathrm{N}$ and $\mathrm{TKN}$ during the experimental. Generally, the effluent nitrogen concentration mainly consisted of $\mathrm{NH}_{4}{ }^{+}-\mathrm{N}, \mathrm{NO}_{3}^{-}-\mathrm{N}, \mathrm{NO}_{2}^{-} \mathrm{N}$, TKN and each one less than $10 \mathrm{mg} / \mathrm{L}$. At the organic loading rate of 0.4-0.6 $\mathrm{kgBOD} / \mathrm{m}^{3}$.day (OLR1 and OLR2), the average of effluent $\mathrm{NH}_{4}{ }^{+}-\mathrm{N}$ concentration was lower than $5 \mathrm{mg} / \mathrm{L}$, the average of effluent $\mathrm{NO}_{2}{ }^{-}-\mathrm{N}$ concentration at this stage also maintained at a low level $(<1.5$ $\mathrm{mg} / \mathrm{L}$ ) and the average of effluent $\mathrm{NO}_{3}{ }^{-}-\mathrm{N}$ concentration was also stable at $9.1 \mathrm{mg} / \mathrm{L}$. The average of effluent TKN was measured ranging from 4.6 to $9.7 \mathrm{mg} / \mathrm{L}$. This result shows that the nitrification process has taken place well, the average treatment efficiency is

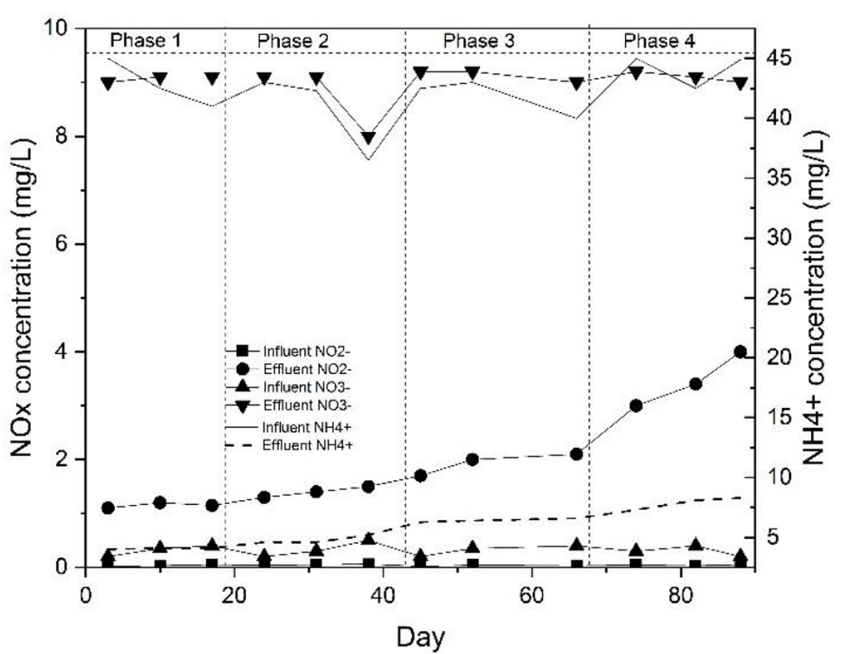

Fig. 3. The transformation of nitrogen compounds in during the experimental.

over $80 \%$, consistent with treatment efficiency reported in Chu et al. [11] also published similar results with a processing efficiency of 77.0 to $91.0 \%$ and concentration of effluent $\mathrm{NH}_{4}{ }^{+}-\mathrm{N}$ below 5 $\mathrm{mg} / \mathrm{L}$. However, when operating at an organic loading rate of 0.8 $\mathrm{kg} \mathrm{BOD} / \mathrm{m}^{3}$.day (OLR3), the average concentration of effluent $\mathrm{NH}_{4}{ }^{+} \mathrm{N}$ increased to $6.4 \pm 0.15 \mathrm{mg} / \mathrm{L}$. At an organic loading rate of $1.0 \mathrm{~kg} \mathrm{BOD} / \mathrm{m}^{3}$.day (OLR4), the average effluent $\mathrm{NH}_{4}{ }^{+}-\mathrm{N}$ and $\mathrm{NO}_{2}{ }^{-}-\mathrm{N}$ concentration increased to $7.9 \pm 0.53$ and $3.5 \pm 0.5 \mathrm{mg} / \mathrm{L}$ respectively, while the average effluent $\mathrm{NO}_{3}^{-}-\mathrm{N}$ concentration remained at $9.1 \mathrm{mg} / \mathrm{L}$. The average treatment effect of OLR3 and OLR4 reduced to $79.4 \pm 1.7 \%$ and $74.0 \pm 2.3 \%$ respectively, similar to a decreasing pattern observed in SS and COD treatment efficiency. Obviously, when operating in the OLR3 and OLR4 stages, it has been shown that $\mathrm{NH}_{4}{ }^{+}-\mathrm{N}$ oxidation to $\mathrm{NO}_{2}^{-}-\mathrm{N}$ has occurred better than the conversion from $\mathrm{NO}_{2}^{-}-\mathrm{N}$ to $\mathrm{NO}_{3}^{-}-\mathrm{N}$. The average $\mathrm{pH}$ value at this stage also changed with a decreasing trend from $7.0 \pm$ 0.1 to $6.4 \pm 0.1$. That reason for the average of effluent $\mathrm{NO}_{3}^{-}-\mathrm{N}$ concentration does not variation much, when compared to the organic loading rates (OLR1 and OLR2). Thus, the group of Nitrobacter (Nitrite oxidation bacteria - NOB) is less effective than the group of Nitrosomonas (Ammonium oxidation bacteria - AOB), when increasing the organic loading rate. Previous studies suggested a higher COD/TN ratio in influent wastewater is necessary to provide sufficient carbon source for denitrification processes [16], and thus OLR3 and OLR4, which have lower COD/TN ratio than that of OLR1 and OLR2, had relatively low TN removal efficiency. In the case of TN concentration, the efficiency tends to reduce slightly from $62.7 \%$ (1st period) to $60.5 \%$ (3rd period) and then reduce in 4th period (55.9\%). Comparison on TN treatment efficiency among OLR1, OLR2, OLR3 and OLR4 (LSD, p < 0.05) showed that OLRs 1 and 2 were statistically significant difference with OLRs of 3 and 4 .

\subsubsection{Phosphorus removal}

Fig. 4 illustrates TP removal efficiency across four ORLs (influent TP concentration ranged from 3.4 to $3.8 \mathrm{mg} / \mathrm{L}$ ). At (OLR1 and OLR2), the average of TP removal efficiency was $40.3 \pm 1.8 \%$ and 44.9 $\pm 2.8 \%$ respectively. This result, the efficiency TP removal is higher 


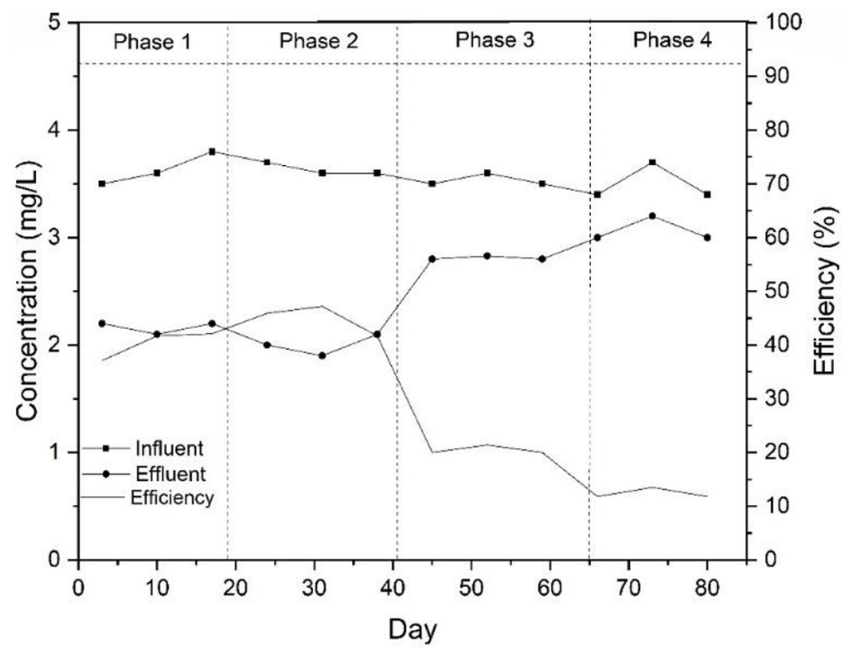

Fig. 4. Effluent phosphorus removal efficiencies in during the experimental.

than the study of Feng et al. [17]., which only achieved $24.2 \pm$ $3.3 \%$ efficiency. However, the removal efficiency decreased significantly from $30^{\text {th }}$ day to the end of OLR2. At organic loading rate of $0.8 \mathrm{kgBOD} / \mathrm{m}^{3}$.day (OLR3) and $1.0 \mathrm{kgBOD} / \mathrm{m}^{3}$.day (OLR4), the average efficiencies of TP removal on continued to decrease at $20.5 \pm 0.8 \%$ and $12.4 \pm 1.0 \%$, respectively. At OLR1 and OLR2, the decreased effluent TP concentrations may be due to microorganisms using the orthophosphate or poly-phosphate form in wastewater to synthesize new cells [26], being absorbed into the biomass and discarded from the system [27]. Study results in Fig. 4 shows the TP treating efficiency of S-MBBR technology is more than $40.0 \%$ in the 1 st and 2nd periods. TP eliminating efficiency is highest in the 5 th week (47.2\%). The total phosphorus removal efficiency for the four phases was 40.3, 44.9; 20.5 and $12.4 \%$, respectively. In addition, OLRs of 1 and 2 were statistically significant difference with OLRs of 3 and 4 ( $\mathrm{p}<0.05)$. However, there is no significant difference between the two loads (OLR1 and OLR2).

The phosphorous in the influent wastewater is incorporated into cell biomass and is removed from the S-MBBR reactor as a result of sludge wasting. The phosphorus removal capacity corresponds to the amount of waste sludge in the S-MBBR. Fig. S3 showed the ratio of the mass of TSS contained in the extracted sludge from a settler. Result indicates a total sludge production of about 0.34-0.50 g TSS/g COD removed for an OLR from 0.4 to $1.0 \mathrm{~kg} \mathrm{BOD} / \mathrm{m}^{3}$.day. The biomass yield illustrated that the process of treated excess sludge as the phosphorus release.

\section{Conclusions}

This study has determined the treatment efficiency of S-MBBR system for domestic wastewater through different organic loading rates (from 0.4 to $1.0 \mathrm{~kg} \mathrm{BOD} / \mathrm{m}^{3}$.day). The highest processing efficiency for COD, SS, TN and TP were $85.0 \pm 12.9 \%$, $85.7 \pm 5.3 \%$, $68.9 \pm 1.7 \%$, and $40.3 \pm 0.2 \%$. Generally, the effluent COD, SS, TN and TP concentrations are within National technical regulation on domestic wastewater limits (QCVN 14-MT:2015/BTNMT, col- umn B1). The results indicate the experimental model have relatively good metabolism of nitrogen compounds and S-MBBR is a potential technology for organic pollution treatment for domestic wastewater in Vietnam. To further investigate the efficiency of S-MBBR technology, different/combined materials can be used as carrier media. Additionally, a range of wastewater such as hospital wastewater, restaurant wastewater should also be assessed, using different operating settings to assess the efficiency of this technology in the developing countries especial in the future.

\section{Acknowledgments}

The authors would like to thank for the research partially funded from Nong Lam University - Ho Chi Minh City, Vietnam (CS-SV17-MTTN-07) and the Ministry of Science and Technology in South Korea through the International Environmental Research Institute (IERI) of Gwangju Institute of Science and Technology (GIST) in FY 2018. The research team also thanks to the Management Board of Co May Dormitory (Linh Trung Ward, Thu Duc District, Ho Chi Minh City), the Center for Environmental Technology and Managerment, Nong Lam University, Ho Chi Minh City for their support in analyzing wastewater samples. Dr. Xuan Hong Do from University of Michigan was supported for their constructive comments and suggestion.

\section{References}

1. Mulkerrins D, Dobson A, Colleran E. Parameters affecting biological phosphate removal from wastewaters. Environ. Int. 2004;30:249-259.

2. Di Trapani D, Christensson M, Torregrossa M, Viviani G, Ødegaard H. Performance of a hybrid activated sludge/biofilm process for wastewater treatment in a cold climate region: Influence of operating conditions. Biochem. Eng. J. 2013;77: 214-219.

3. Zhao Y, Cao D, Liu L, Jin W. Municipal wastewater treatment by moving-bed-biofilm reactor with diatomaceous earth as carriers. Water Environ. Res. 2006;78:392-396.

4. Barwal A, Chaudhary R. To study the performance of biocarriers in moving bed biofilm reactor (MBBR) technology and kinetics of biofilm for retrofitting the existing aerobic treatment systems: A review. Rev. Environ. Sci. Biotechnol. 2014;13:285-299.

5. Guo W, Ngo HH, Dharmawan F, Palmer CG. Roles of polyurethane foam in aerobic moving and fixed bed bioreactors. Bioresour. Technol. 2010;101:1435-1439.

6. Walser SM, Brenner B, Wunderlich A, et al. Detection of Legionella-contaminated aerosols in the vicinity of a bio-trickling filter of a breeding sow facility-A pilot study. Sci. Total Environ. 2017;575:1197-1202.

7. Zhang X, Song Z, Guo W, et al. Behavior of nitrogen removal in an aerobic sponge based moving bed biofilm reactor. Bioresour. Technol. 2017;245:1282-1285.

8. Sbardella L, Comas J, Fenu A, Rodriguez-Roda I, Weemaes M. Advanced biological activated carbon filter for removing pharmaceutically active compounds from treated wastewater. 
Sci. Total Environ. 2018;636:519-529.

9. Bakar SNHA, Hasan HA, Mohammad AW, et al. A review of moving-bed biofilm reactor technology for palm oil mill effluent treatment. J. Clean. prod. 2018;171:1532-1545.

10. Rusten B, Eikebrokk B, Ulgenes Y, Lygren E. Design and operations of the Kaldnes moving bed biofilm reactors. Aqua. Eng. 2006;34:322-331.

11. Chu L, Wang J, Quan F, Xing XH, Tang L, Zhang C. Modification of polyurethane foam carriers and application in a moving bed biofilm reactor. Proc. Biochem. 2014;49:1979-1982.

12. Abzazou T, Araujo RM, Auset M, Salvadó H. Tracking and quantification of nitrifying bacteria in biofilm and mixed liquor of a partial nitrification MBBR pilot plant using fluorescence in situ hybridization. Sci. Total Environ. 2016;541:1115-1123.

13. Deng L, Guo W, Ngo HH, et al. New functional biocarriers for enhancing the performance of a hybrid moving bed biofilm reactor-membrane bioreactor system. Bioresour. Technol. 2016;208:87-93.

14. Peng P, Huang H, Ren H, et al. Exogenous N-acyl homoserine lactones facilitate microbial adhesion of high ammonia nitrogen wastewater on biocarrier surfaces. Sci. Total Environ. 2018;624:1013-1022.

15. Luo Y, Guo W, NgoHH, et al. Removal and fate of micropollutants in a sponge-based moving bed bioreactor. Bioresour. Technol. 2014;159:311-319.

16. Chu L, Wang J. Comparison of polyurethane foam and biodegradable polymer as carriers in moving bed biofilm reactor for treating wastewater with a low $\mathrm{C} / \mathrm{N}$ ratio. Chemosphere 2011;83:63-68.

17. Feng Q, Wang Y, Wang T, et al. Effects of packing rates of cubic-shaped polyurethane foam carriers on the microbial community and the removal of organics and nitrogen in moving bed biofilm reactors. Bioresour. Technol. 2012;117:201-207.

18. Zhang X, Chen X, Zhang C, Wen H, Guo W, Ngo HH. Effect of filling fraction on the performance of sponge-based moving bed biofilm reactor. Bioresour. Technol. 2016;219:762-767.

19. Thanh BX, Berg H, Nguyen LNT, Da CT. Effects of hydraulic retention time on organic and nitrogen removal in sponge membrane bioreactor treating catfish farm wastewater in the tropics. Environ. Eng. Sci. 2013;30:194-199.

20. Guo W, Ngo HH, Palmer CG, Xing W, Hu AYJ, Listowski A Roles of sponge sizes and membrane types in a single stage sponge-submerged membrane bioreactor for improving nutrient removal from wastewater for reuse. Desalination 2009;249: 672-676.

21. Deng L, Ngo HH, Guo W, Zhang H. Pre-coagulation coupled with sponge-membrane filtration for organic matter removal and membrane fouling control during drinking water treatment. Water Res. 2019;157:155-166.

22. Nguyen TT, Bui XT, Dang BT, et al. Effect of ciprofloxacin dosage on the performance of sponge membrane bioreactor treating hospital wastewater. Bioresour. Technol. 2019;273:573-580.

23. Vo TK, Bui XT, Chen SS, et al. Hospital wastewater treatment by sponge membrane bioreactor coupled with ozonation process. Chemosphere 2019;230: 377-383.

24. Kermani M, Bina B, Movahedian H, Amin MM, Nikaein M. Application of moving bed biofilm process for biological organics and nutrients removal from municipal wastewater. Am. J. Environ. Sci. 2008;4:675-682.

25. Bassin J, Dias I, Cao S, et al. Effect of increasing organic loading rates on the performance of moving-bed biofilm reactors filled with different support media: Assessing the activity of suspended and attached biomass fractions. Proc. Saf. Environ. Prot. 2016;100:131-141.

26. Sedlak RI. Phosphorus and nitrogen removal from municipal wastewater: Principles and practice. Boca Raton (FL): CRC press; 1991.

27. Metcalf E. Wastewater engineering treatment and resource recovery. 5th ed. New York: McGraw-Hill Education; 2014 